\title{
Extrusive, Intrusive Luxation and Avulsion in a 7-Year- Old Child: One year of Clinical, Radiographic and Tomographic Follow-Up
}

\author{
Luxación Extrusiva e Intrusiva y Avulsión en un Niño de Siete Años de Edad: \\ Un año de Seguimiento Clínico, Radiográfico y Tomográfico
}

\begin{abstract}
Thais Machado de Carvalho Coutinho; Alexandre Marques Paes da Silva1; Thamires Chagas de Medeiros²; Patricia Nivoloni Tannure Veiga de Almeida ${ }^{2}$; Manuel Marques Ferreira ${ }^{3} \&$ Dennis de Carvalho Ferreira ${ }^{1,3}$
\end{abstract}

COUTINHO, T. M. C.; DA SILVA, A. M. P.; DE MEDEIROS, T. C.; DE ALMEIDA, P. N. T. V.; FERREIRA, M. M. \& FERREIRA, D. C. Extrusive, intrusive luxation and avulsion in a 7-year-old child: One year of clinical, radiographic and tomographic follow-up. Int. J. Odontostomat., 15(4):867-872, 2021.

ABSTRACT: Dental trauma is a serious injury that occurs frequently in children and adolescents, requiring urgent dental care. The upper central incisors are the most vulnerable teeth to such traumatic injuries, which can lead to bite restrictions, difficulties in phonation and esthetical questions. The aim of this study was to report the success of a conservative approach carried out on a 7-year-old patient, victim of multiple dental trauma, involving permanent and deciduous teeth. The male patient fell from his own height, causing soft tissue lacerations and dento-alveolar traumatism in both deciduous and permanent teeth. Complementary examinations (periapical radiographs and computed tomography) were carried out. Based on the diagnoses the patient was referred to specialists for appropriate treatment. The present report highlights the importance of an early diagnosis, suitable treatment and follow-up of patients after an alveoli-dental trauma and shows the direct relationship of this approach with the prognosis of the patient and the tooth.

KEY WORDS: oral trauma and self-injury, pediatric dentistry, oral health.

\section{INTRODUCTION}

Accidents involving deciduous and/or permanent teeth, especially in childhood are very common, and their consequences are directly related to the severity of the lesions. These lesions range from minor damage to soft tissues to total displacement of a tooth or teeth (dental avulsion) (Andreasen et al., 2012; Malmgren et al., 2012).

Dental trauma in children and adolescents is considered a public health problem in Brazil and the world. It can have negative consequences related to interpersonal relationships (Prata et al., 2000; Andreasen et al., 2012). Such traumas may involve any of three anatomical structures: the tooth itself; adjacent soft tissues; and the alveolar bone (Jorge et al., 2012; Andreasen et al., 2012). Therefore, complex and multidisciplinary treatment, ranging from simple restorations to surgery and orthodontics is often needed (Leathers \& Gowans, 2013).

Dental trauma must always be treated as an emergency, so that it can be evaluated as soon as possible. Immediate care helps relieve pain and facilitates repositioning procedures of any tooth that has been displaced from its original position, and consequently, improving the prognosis (Andreasen \& Andreasen, 2001). Prognoses are often dubious and may vary according to the damage caused and treatment proposed case by case (Keçeci et al., 2005).

It is important that parents and teachers are aware of these issues, since the steps taken

${ }^{1}$ Estácio de Sá University (UNESA), Rio de Janeiro, Brazil.

${ }^{2}$ Federal University of Rio de Janeiro, Brazil.

${ }^{3}$ Coimbra University, Coimbra, Portugal. 
immediately after the onset of a trauma can directly interfere with the prognosis (Al-Musawi et al., 2017). The type of trauma, the time elapsed between the trauma and the initial care and the consequences of the trauma itself will determine the specific treatment to be carried out (Oliveira et al., 2004).

Protocols to guide dental practitioners on how to proceed in the face of various types of trauma can be found in the present literature. However, these protocols are often neglected, resulting in disastrous consequences for the patient (Macena et al., 2009).

Dental trauma can affect individuals at different times of their lives, however, some factors are considered predisposing to the occurrence of dental trauma, such as: gender, age, overjet accentuated to inadequate lip coverage, obesity. And, especially during sports practice, where dental trauma is an eminent and unpredictable risk (Jorge et al.; Piovesan et al., 2012; Paiva et al., 2015).

Regarding the permanent dentition, the proposed treatment should always be geared to keep the tooth order in the oral cavity, properly positioned, thus avoiding its early loss and/or resorption or loss of alveolar bone, maintaining aesthetic and harmonious functionality to the patient (Prata et al.). On the other hand, in cases of dental avulsion of deciduous teeth there is a consensus in current literature that they should not be reimplanted as this may cause irreversible damage to their successors, the permanent dentition (Wendt et al., 2010; Andreasen et al., 2012; Lenzi \& Trope, 2012). Moreover, trauma to deciduous dentition can lead to sequelae in the successive dentition, such as stains on enamel, hypoplasias and eruption disturbances (Xavier et al., 2011).

The rare occurrence of intrusion injuries, $6,2 \%$ in the permanent dentition and $12,9 \%$ in the deciduous dentition (Lydia et al., 2020), has resulted in limited studies to support suggested treatment regimes. The aim of this case was to report the success of a conservative approach of severe luxation injuries, in a 7-year-old patient, affecting permanent and deciduous teeth. The management reported was based in a recent guideline published by the British Society of Pediatric Dentistry.

This study was previously approved by Ethics and Research Committee (CEP) - Veiga de Almeida University (UVA) - Protocol 2.905.244.

\section{CASE REPORT}

A 7-year-old male Caucasian child from the city of Rio de Janeiro was attended as an emergency having suffered a fall from his own height impacting his face and teeth on the floor at his school.

He received first aid treatment by the school doctor, who reported the avulsion of tooth 52 , displacement of teeth 11, 21 and 62 and some soft tissue lacerations. At the same time, asepsis of the soft tissue, the teeth and alveolus lacerations of the avulsed element was performed (Fig. 1a and b).

The second examination and care were performed about 3 hours later by a dental surgeon on the same day as the trauma. Clinical and radiographic examinations revealed: the absence of tooth 52 , which according to the mother's report had been avulsed at the time of the trauma; complete displacement of the tooth 62 from its socket; extrusive luxation of the element 21; and a possible intrusion of element 11 , which, could be in an eruptive movement due to the young age of the patient. Radiographic examination did not reveal any root fractures, but teeth 11 and 21 presented incomplete rhizogenesis. They were in an extremely immature stage of formation, since only 113 of their roots hadformed (Stage 7 of Nolla). Consequently, the decision was made to extract
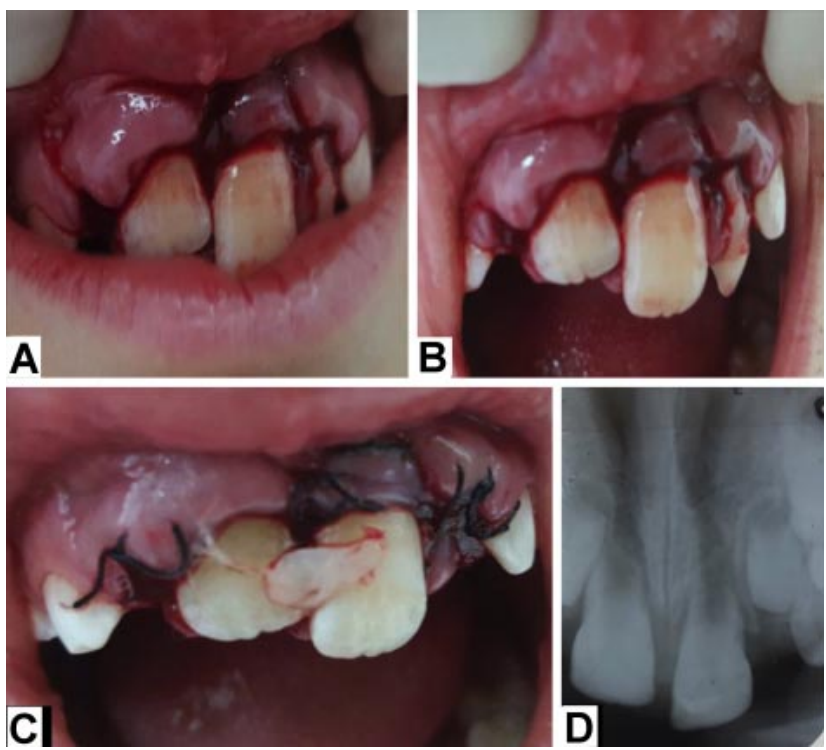

Fig. 1. (A, B) Images of the patient at the first clinical examination; (C) Images of the patient immediately after the initial clinical care showing the sutures of the soft tissues and extraction of tooth 62; (D) Radiograph of teeth 21 and 11 showing incomplete rhizogenesis. 
element 62, reposition the elements 11 and 21 into their respective sockets with semi-rigid containment for 15 days. Also, at this time the suturing of the soft tissues involved was carried out (Fig. 1c and d). Finally, the caregivers of the patient were given relevant guidelines for trauma patients, such as the use of ice, liquid/pasty foods and no physical force should be made in this region.

The patient was collaborative and was in good general health. Analgesic and anti-inflammatory medicines were prescribed to control pain and any inflammatory reaction (Ibuprofen solution $1 \mathrm{drop} / \mathrm{Kg}$ ) for three days.

The semi-rigid restraint was removed after the 15-day period, and a clinical examination revealed gingival tissue still under repair, and tooth 21 presented grade II mobility. Cone Beam Computed Tomography (CBCT) scans were performed to obtain a more effective multiplanar analysis of the teeth involved as well as their supporting structures. This examination revealed a fracture of the anterior nasal spine and the displacement of the tooth 21 from its socket. Teeth 11 and 21 presented incomplete rhizogenesis, but without any tomographic signs of pulpal and periradicular alterations compatible with the clinical condition of pulp sensitivity, considering the patient complained of sensitivity when consuming cold food or drinks (Fig. 2). Therefore, at this point the proposed treatment was orthodontic intrusion and clinical follow-ups to monitor for any pulp and periradicular alterations.

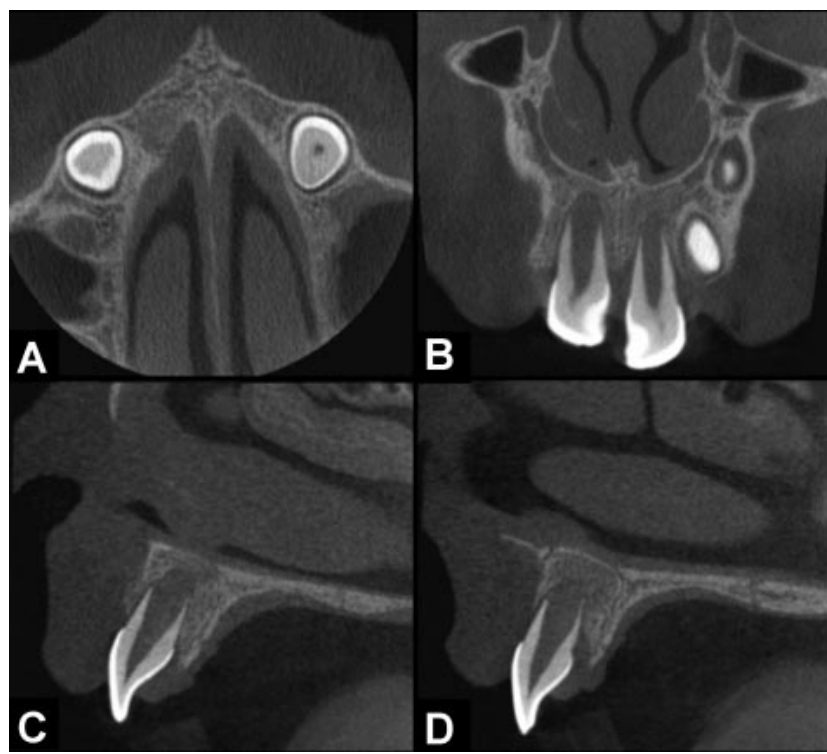

Fig. 2. (A) Tomographic images of the patient showing fracture of the anterior nasal spine; $(B, C, D)$ displacement of element 21 from its socket.
After a 1-year follow-up period, root development had progressed and there were no signs or symptoms of pulpal and periradicular alterations, confirming the success of the approach described above (Figs. 3 and 4).
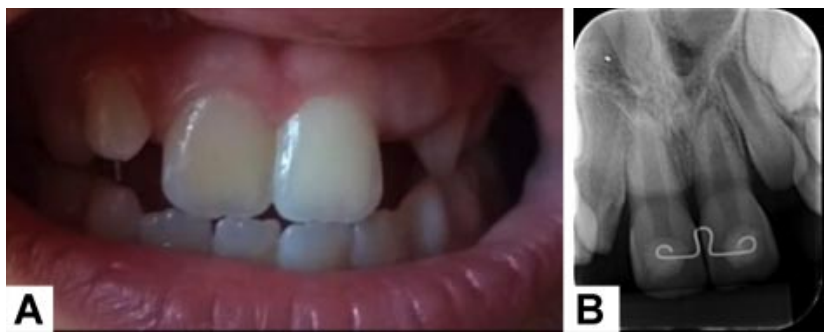

Fig. 3. (A) Image of the patient 1 year after the accident; (B) Radiography 1 year after the accident, showing complete rhizogenesis (Stage 10 of Nolla) and no radiographic signs of pulpal alterations.

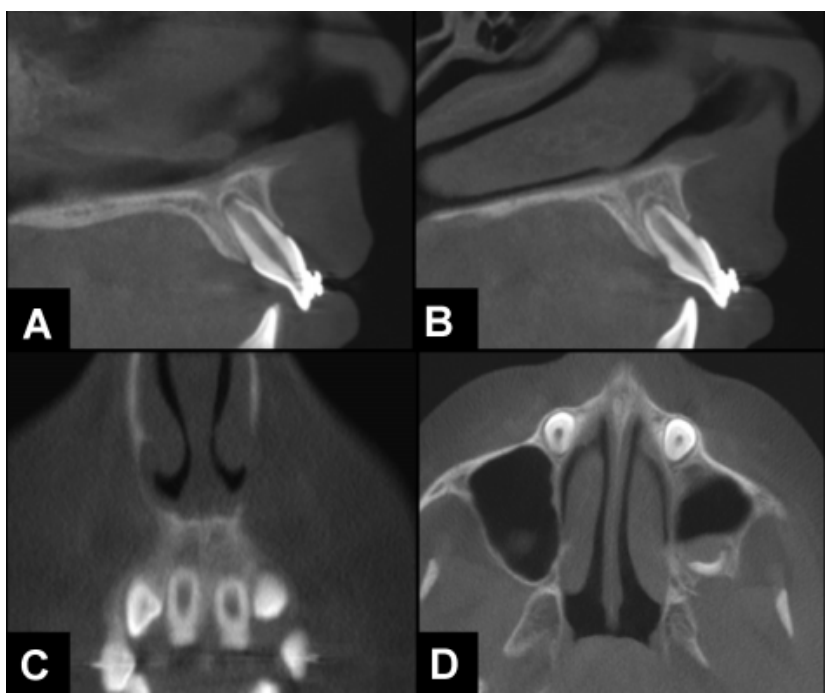

Fig. 4. (A) 1 year after the accident the tomographic image, revealed there was no pulpal alteration, a very minor periradicular lesion in tooth 11; and the same can be said for tooth 21 in (B) (both 11 \& 12 were in Stage 10 of Nolla); (C) an occlusal view of teeth 11 and 21; (D) a cross section showing the calcification of the anterior nasal spine.

\section{DISCUSSION}

Dental trauma in children and adolescents involving deciduous, mixed or permanent dentition should be considered as emergency cases. They occur quite frequently and require a prompt response including a thorough clinical examination of all structures involved: teeth, bone tissue and adjacent soft tissues (Soriano et al., 2007). 
COUTINHO, T. M. C.; DA SILVA, A. M. P.; DE MEDEIROS, T. C.; DE ALMEIDA, P. N. T. V.; FERREIRA, M. M. \& FERREIRA, D. C. Extrusive, intrusive luxation and avulsion in a 7year-old child: One year of clinical, radiographic and tomographic follow-up. Int. J. Odontostomat., 15(4):867-872, 2021.

Accidents involving teeth can range from small concussions to a complete displacement of the tooth from its socket, thus characterizing a dental avulsion as in the case described above, where the element 52 was completely displaced from the oral cavity (Andreasen et al., 2012). As this was a deciduous tooth, it was not reimplanted, since there is abundant scientific evidence in the literature that avulsed primary teeth should not be reimplanted, as this could cause irreversible damage to the corresponding permanent dentition. In the present study, tooth 62 suffered an extrusive dislocation and presented high mobility. However, despite being close to its exfoliation stage, it was decided to exoditate it, in order to avoid any damage to its successor (Figs. 1 and 2) (do Espírito Santo Jácomo \& Campos, 2009; Andreasen et al., 2012; Mendoza-Mendoza et al., 2015).

As in the present study the literature shows a higher prevalence of dental trauma involving males, which is probably justified as boys are involved in more aggressive activities while playing and in sports (Arikan \& Sönmez, 2012).

In recent years, several studies have shown that incisors are more commonly involved in dental trauma, especially the central incisors, than other teeth (Maillet et al., 2011).

The causes that can result in traumas involving dental elements are numerous and include: automobile accidents; practice of sports; collisions with other individuals, and falling from one's own height among others. In the present study, the person in charge at the school and the patient himself reported that he, the patient, collided with a "little friend" and then fell. This fall from his own height resulted in the consequences described above in this case report (Skaare \& Jacobsen, 2003; Andreasen et al., 2012).

The knowledge of parents, guardians, caregivers and teachers may be of fundamental importance in the prognosis for a dental trauma. (Kruse et al., 2015). In the present study, first aid was carried out at the school, where only asepsis was carried out; however the mother was contacted and as soon as she saw her son she realized that it was not a "simple school incident", and decided that he required more specific medical attention. Thus, she took her son to a emergency out-patient clinic, which confirmed a more serious consequence of the injury: teeth (21 and 62) were dislocated from their respective sockets; there was a possible intrusion trauma of element 11 , which, however, could not be confirmed as the age of the patient was compatible with the eruption phase of the tooth in question (stage 7 of Nolla). Teeth in the process of eruption, with the apical foramen still open and with a large diameter, have a greater chance of revascularization, thus reducing the chances of pulp necrosis. (Andreasen et al., 1986).

As described previously, element 62 was extracted, the soft tissue sutured and a semi-rigid restraint was placed on teeth 11 and 21 for a period of 15 days. The treatment proposed for this type of trauma (intrusion) is much discussed in the literature. Some authors defend the use of semi-rigid immobilizations, as in the present case report, but others do nothing at all, and just wait for the spontaneous recovery, monitoring the movement of the element radiographically. On the other hand, some authors have proposed the use of orthodontics in order to avoid ankylosis of these traumatized teeth. (Andreasen et al., 1986; Andreasen et al., 2012).

In the present study a CBCT scan was performed, which in endodontics allows precise actions to be planned and executed, as the periradicular region with its changes in size and shape and the relation with the adjacent noble structures can be located easily (Nair \& Nair, 2010). In agreement with the data of a systematic review (Phothikhun et al., 2012) this case highlights the accuracy of the CBCT in relation to a radiographic examination, where the CBCT scan was able to show the displacement of the tooth 21 from its socket and anterior nasal spine fracture, which was not seen in the radiographic examination. However, the risk of radiation exposure should be considered since the radiation of a CBCT scan is superior to a periapical radiograph (Mota de Almeida et al., 2014; European Society of Endodontology et al., 2014; Lima et al., 2014).

Reduced radiation doses are especially important for children when considering tomographic exams (Cohenca \& Shemesh, 2015). The American Society of Endodontists recommends that in cases of high complexity exams such as CBCT are acceptable (European Society of Endodontology et al.).

The success of the treatment undertaken here portrayed a multidisciplinary approach and the use of protocols described in the literature (Macenan et al.).

The present study describes a clinical case of a patient with dental trauma to the mixed dentition. An individual in mixed dentition, who undergoes some kind 
COUTINHO, T. M. C.; DA SILVA, A. M. P.; DE MEDEIROS, T. C.; DE ALMEIDA, P. N. T. V.; FERREIRA, M. M. \& FERREIRA, D. C. Extrusive, intrusive luxation and avulsion in a 7year-old child: One year of clinical, radiographic and tomographic follow-up. Int. J. Odontostomat., 15(4):867-872, 2021.

of dental trauma, should seek dental care as soon as possible, and should be evaluated using a multidisciplinary approach by examining the teeth, alveolar bone and adjacent soft tissues involved. Moreover, the time elapsed between the dental trauma and first care should be as short as possible, as this directly affects the prognosis of the traumatized teeth.

In conclusion, not only dental professionals should be aware of the need for immediate management in cases of dental trauma, but teachers, caregivers and parents should also be made aware of this urgency through informative campaigns and leaflets.

Ethics approval and consent to participate. This study was previously approved by CEP-UVA - Protocol 2.905.244.

All the authors confirm that informed written consent to publish the work was signed and accepted by legal guardian of the patient, considering that the patient was a minor (7 years old).

Consent for publication. Written informed consent was obtained from the mother of the patient. In this informed consent, the patient's caregiver, read and approved the for publication.

AUTHORS' CONTRIBUTIONS. All authors have read and approved the manuscript.

Conception and design, collection, analysis, interpretation of data and active participation in the discussion of results: TMCC; AMPS; DCF.

Article Writing or Critical Review of Relevant Intellectual Content: TMCC; AMPS; MMF; DCF.

Review and final approval of the version to be published TMCC; AMPS; TCM; MMF; DCF.

Accordance with all aspects of the manuscript in terms of truthfulness or integrity of information: TMCC; AMPS; TCM; PNT; MMF; DCF.

COUTINHO, T. M. C.; DA SILVA, A. M. P.; DE MEDEIROS, T. C.; DE ALMEIDA, P. N. T. V.; FERREIRA, M. M. \& FERREIRA, D. C. Luxación extrusiva e intrusiva y avulsión en un niño de siete años de edad: Un año de seguimiento clínico, radiográfico y tomográfico. Int. J. Odontostomat., 15(4):867-872, 2021.

RESUMEN: El trauma dentario es una lesión grave que ocurre con frecuencia en niños y adolescentes y requiere atención dental urgente. Los incisivos centrales superiores son las piezas dentarias más vulnerables a dichos traumas, pudiendo generar restricciones en la mordida, la fonación y a nivel estético. El objetivo de este estudio fue reportar el éxito de un enfoque conservador llevado a cabo en un niño de 7 años de edad, víctima de un trauma dentario múltiple, que involucró tanto dientes temporales como permanentes. El paciente masculino, cayó desde su propia altura, causando laceraciones en los tejidos blandos y traumatismo dentoalveolar en piezas de ambas denticiones. Se llevaron a cabo exámenes complementarios (radiografías periapicales y tomografía computarizada). Basado en el diagnóstico, el paciente fue referido a especialistas para realizar el tratamiento apropiado. El presente reporte destaca la importancia de un diagnóstico precoz, un tratamiento adecuado y el seguimiento de los pacientes luego de un trauma dento-alveolar, y cómo este enfoque muestra relación directa con el pronóstico del paciente y del diente.

PALABRAS CLAVE: trauma oral y autolesiones, odontopediatría, salud oral.

\section{REFERENCES}

Al-Musawi, A.; Al-Sane, M. \& Andersson, L. Smartphone app as an aid in the emergency management of avulsed teeth. Dent. Traumatol., 33(1):13-8, 2017.

Andreasen, F. M.; Zhijie, Y. \& Thomsen, B. L. Relationship between pulp dimensions and development of pulp necrosis after luxation injuries in the permanent dentition. Endod. Dent. Traumatol., 2(3):90-8, 1986.

Andreasen, J. O. \& Andreasen, F. M. Texto e atlas colorido de traumatismo dental. 3rd ed. Porto Alegre, Artmed, 2001.

Andreasen, J. O.; Lauridsen, E.; Gerds, T. A. \& Ahrensburg, S. S. Dental trauma guide: a source of evidence-based treatment guidelines for dental trauma. Dent. Traumatol., 28(5):142-7, 2012.

Arikan, V. \& Sönmez, H. Knowledge level of primary school teachers regarding traumatic dental injuries and their emergency management before and after receiving an informative leaflet. Dent. Traumatol., 28(2):101-7, 2012.

Cohenca, N. \& Shemesh, H. Clinical applications of cone bean computed tomography in endodontics: a comprehensive review. Quintessence. Int., 46(8):657-68, 2015.

do Espírito Santo Jácomo, D. R. \& Campos, V. Prevalence of sequelae in the permanent anterior teeth after trauma in their predecessors: a longitudinal study of 8 years. Dent. Traumatol., 25(3):300-4, 2009.

European Society of Endodontology; Patel, S.; Durack, C.; Abella, F.; Roig, M.; Shemesh, H.; Lambrechts, P. \& Lemberg, K. European society of endodontology position statement: the use of CBCT in endodontics. Int. Endod. J., 47(6):502-4, 2014.

Jorge, K. O.; Oliveira Filho, P. M.; Ferreira, E. F.; Oliveira, A. C.; Vale, M. P. \& Zarzar, P. M. Prevalence and association of dental injuries with socioeconomic conditions and alcohol/drug use in adolescents between 15 and 19 years of age. Dent. Traumatol., 28(2):136-41, 2012.

Keçeci, A. D.; Eroglu, E. \& Baydar, M. L. Dental trauma incidence and mouthguard use in elite athletes in Turkey. Dent. Traumatol., 21(2):76-9, 2005.

Kruse, C.; Spin-Neto, R.; Wenzel, A. \& Kirkevang, L. L. Cone bean computed tomography and periapical lesions: a systematic review analysing studies on diagnostic efficacy by a hierarchical model. Int. Endod. J., 48(9):815-28, 2015. 
COUTINHO, T. M. C.; DA SILVA, A. M. P.; DE MEDEIROS, T. C.; DE ALMEIDA, P. N. T. V.; FERREIRA, M. M. \& FERREIRA, D. C. Extrusive, intrusive luxation and avulsion in a 7 year-old child: One year of clinical, radiographic and tomographic follow-up. Int. J. Odontostomat., 15(4):867-872, 2021.

Leathers, R. D. \& Gowans, R. E. Office-based management of dental alveolar trauma Atlas Oral Maxillofac. Surg. Clin. North Am., 21(2):185-97, 2013.

Lenzi, R. \& Trope, M. Revitalization procedures in two traumatized incisors with different biological outcomes. J. Endod., 38(3): 4114, 2012.

Lima, D.; Benetti, F.; Ferreira, L. L.; Dezan-Júnior, E.; Gomes-Filho, J. E. \& Cintra, L. T. A. Aplicações Endodônticas da Tomografia Computadorizada Cone-Bean. Braz. J. Surg. Clin. Res., 6(3):309, 2014.

Macena, M. C. B.; Leite, A. C.; Colares, V.; Vieira, S. \& de Carvalho Neto, L. G. Protocolo clínico de avaliação e conduta no traumatismo dentário. Rev. bras. promoç. saúde., 22(2):120-7, 2009.

Maillet, M.; Bowles, W. R.; McClanahan, S. L.; John, M. T. \& Ahmad, M. Cone-beam computed tomography evaluation of maxillary sinusitis. J. Endod., 37(6):753-7, 2011.

Malmgren, B.; Andreansen, J. O.; Flores, M. T; Robertson, A.; DiAngelis, A, J.; Andersson, L.; Cavalleri, G.; Cohenca, N.; Day, P.; Hicks, M. L.; Malmgren, O.; Moule, A. J.; Onetto, J. \& Tsukiboshi, M. International Association of Dental Traumatology guidelines for the management of traumatic dental injuries: 3 . Injuries in the primary dentition. Dent. Traumatol., 28(3):74-182, 2012.

Mendoza-Mendoza, A.; Iglesias-Linares, A.; Yañez-Vico, R. M. \& Abalos-Labruzzi, C. Prevalence and complications of trauma to the primary dentition in a subpopulation of Spanish children in southern Europe. Dent. Traumatol., 31(2):144-9, 2015.

Mota de Almeida, F. J.; Knutsson, K. \& Flygare, L. The effect of cone beam CT (CBTC) on therapeutic decision marking in endodontics. Dentomaxillofac. Radiol., 43(4):20130137, 2014.

Nair, U. P. \& Nair, M. K. Maxillary sinusitis of odontogenic origin: conebeam volumetric computerized tomography-aided diagnosis. Oral Surg. Oral Med. Oral Pathol. Oral Radiol. Endod., 110(6):e53-7, 2010.

Oliveira, F. A. M.; de Oliveira, M. G.; Orso, V. A. \& de Oliveira, V. R. Traumatismo dentoalveolar: revisão de literatura. Rev. cir. traumatol. buco-maxilo-fac., 4(1):15-21, 2004.

Paiva, P. C.; Paiva, H. N.; Oliveira Filho, P. M.; Lamounier, J. A.; Ferreira, R. C.; Ferreira, E. F. \& Zarzar, P. M. Prevalence of traumatic dental injuries and its association with binge drinking among 12-yearolds: a population-based study. Int. J. Paediatr. Dent., 25(4):23947, 2015.

Phothikhun, S.; Suphanantachat, S.; Chuenchompoonut, V. \& Nisapakultorn, K. Cone-beam computed tomographic evidence of the association between periodontal bone loss and mucosal thickening of the maxillary sinus. J. Periodontol., 83(5): 557-64, 2012.

Piovesan, C.; Guedes, R. S.; Casagrande, L. C. \& Ardenghi, T. M. Socioeconomic and clinical factors associated with traumatic dental injuries in Brazilian preschool children. Braz. Oral Res., 26(5):46470, 2012.

Prata, T. H. C.; Duarte M. S. R.; Miquilito, J. L.; Valera M. C.; \& Araújo, M. A. M. Etiology and frequency of the dental trauma injuries in patients from Dental Trauma Center in the São José dos Campos School of Dentistry, São Paulo State University. Rev. odontol. UNESP, 29(1-2):43-53, 2000.

Skaare, A. B. \& Jacobsen, I. Dental injuries in Norwegians aged 7-18 years. Dent. Traumatol., 19(2):67-71, 2003.

Soriano, E. P.; Caldas, A., Jr.; Diniz De Carvalho, M. V. \& Amorim Filho, $\mathrm{H}$. Prevalence and risk factors related to traumatic dental injuries in Brazilian schoolchildren. Dent. Traumatol., 23(4):23240, 2007.

Wendt, F. P.; Torriani, D. D.; Assunção, M. C.; Romano, A. R.; Bonow, M. L.; da Costa, C. T.; Goettems, M. L. \& Hallal, P. C. Traumatic dental injuries in primary dentition: Epidemiological study among preschool children in South Brazil. Dent. Traumatol., 26(2):16873, 2010 .
Xavier, C. B.; Faria, G. D.; Vogt, D. F.; Collares, K. F. \& Dickel, R. Study of dentoalveolar trauma in patients treated at an Oral and Maxillofacial Surgery facial. Rev. gaúch. odontol., 9(4):565-70, 2011.

Corresponding author:

Alexandre Marques Paes da Silva

General Ivan Raposo, Street, 596/105

Barra da Tijuca

Rio de Janeiro

BRAZIL

E-mail: xandemps@gmail.com 